\title{
A study on cytology of soft tissue spindle cell tumors with histopathological correlation wherever possible
}

\author{
Dhanya K. ${ }^{1}$, Sateesh Chavan S. ${ }^{2}$ \\ ${ }^{1}$ Dr. Dhanya K., Post Graduate Student, ${ }^{2}$ Dr. Sateesh Chavan S, Associate Professor, Department of Pathology, Karnataka \\ Institute of Medical Sciences, Hubballi, Karnataka, India.
}

Corresponding Author: Dr. Sateesh Chavan S., Associate Professor, Department of Pathology, Karnataka Institute of Medical Sciences, Hubballi, Karnataka, India. E-mail: chavanelite05@gmail.com

\begin{abstract}
Introduction: Spindle cell tumors constitute an important component of soft tissue tumors. Fine needle aspiration cytology provides a predictive diagnosis of type and nature of these neoplasms. Methods: This study was conducted for a period of four years. Results: A total of 124 cases were diagnosed as soft tissue spindle cell tumors cytologically. Of these, 86 $(69.35 \%)$ cases were benign and 38 (30.64\%) were malignant tumors. 52 cases were available for histopathological follow up of which 49 cases $(94.23 \%)$ showed positive correlation. Though there are no specific tissue architectural patterns in cytological smears, they are helpful in providing predictive diagnosis of benign or malignant nature of the tumour and in many cases also of specific tumor type. However, histopathology is considered as "gold standard" in diagnosing spindle cell tumors. Ancillary techniques are helpful in providing definitive diagnosis thus increasing the diagnostic accuracy of FNAC. There were 2 false negative cases which were cytologically diagnosed as Schwannoma and Neurofibroma because of the presence of wavy spindle cells and blood but both cases were diagnosed as malignant peripheral nerve sheath tumor on histopathology. There was 1 false positive case cytologically diagnosed as malignant spindle cell tumor but histopathologically diagnosed as Pleomorphic lipoma. Conclusion: Cytological and histopathological correlation was available in 36 benign tumors and 16 malignant tumors. Among benign tumors, 94.44\% (34 cases) showed positive correlation, $5.56 \%$ ( 2 cases) showed negative correlation. Whereas among malignant tumors, 93.75\% (15 cases) showed positive correlation and $6.25 \%$ ( 1 case) showed negative correlation between cytologic and histopathologic diagnosis.
\end{abstract}

Keywords: Soft tissue, Spindle cell tumors, Cytology, Correlation.

\section{Introduction}

The field of soft tissue tumors is enormously vast, and yet as cytologically, relatively undiscovered. The large range of different types of soft tissue tumors, their diagnosis and classification becomes one of the difficult areas in pathology [1]. Spindle cell tumors constitute an important component of soft tissue tumors. The natural course of soft tissue tumours is unpredictable and very aggressive if not diagnosed early. Coupled with their inherently challenging microscopic nature, ranging from benign to borderline to malignant, and their generally hetero-geneous composition, spindle cell tumors can be a source of diagnostic confusion [2].

Fine needle aspiration cytology (FNAC) is a useful screening tool which is least invasive and cost-effective procedure. Though there are no specific tissue

Manuscript received: $30^{\text {th }}$ June 2019

Reviewed: $10^{\text {th }}$ July 2019

Author Corrected: $16^{\text {th }}$ July 2019

Accepted for Publication: $22^{\text {nd }}$ July 2019 architectural patterns in cytological smears, they are helpful in providing predictive diagnosis of benign or malignant nature of the tumour and in many cases also of specific tumor type. However, histopathology is considered as "gold standard" in diagnosing spindle cell tumors. Ancillary techniques are helpful in providing definitive diagnosis thus increasing the diagnostic accuracy of FNAC.

\section{Methodology}

Study period: Present study includes two years retrospective and two years prospective cases presented between June 2013 and May 2017

Study setting: The department of pathology, KIMS, Hubballi.

Study subjects: The study group constituted 124 cases with palpable soft tissue mass.

Data collection: After detailed history, clinical examination and informed consent of patient, fine needle 
aspiration was performed under aseptic precautions using disposable 22-gauge needle and $10 \mathrm{cc}$ syringe. One air dried smear was subjected to adequacy evaluation under toluidine preparation on the site. Wet smears immediately fixed in isopropyl alcohol were stained with hematoxylin and eosin, PAP stain. Dry-fixed smears were Wright's stained and studied for cytological details. Inclusion criteria: Patients of all age groups and both sex were included in the study whereas patients with skin

\section{Original Research Article}

infection at the site of aspiration, those with hemorrhagic diathesis were excluded from the study.

Excised surgical specimen and biopsies were processed routinely and stained with hematoxylin and eosin. Cytological results were correlated with histopathological findings wherever possible.

\section{Results}

A total of 124 cases of soft tissue spindle cell tumors were studied. Of these, 86(69.35\%) cases were benign spindle cell tumors, 38(30.64\%) cases were cytologically malignant. Males were more commonly affected with 55.64\% (69 cases) and females accounted for $44.35 \%$ (55 cases). Male to Female ratio was 1.23:1.

Most common age group affected was $3^{\text {rd }}$ decade $(24.19 \%, 30$ cases $)$ followed by $5^{\text {th }}$ decade $(18.54 \%, 23$ cases $), 4^{\text {th }}$ decade $(17.74 \%, 22$ cases $), 7^{\text {th }}$ decade $(15.32 \%, 19$ cases $), 2$ nd decade $(11.29 \%, 14$ cases $), 6^{\text {th }}$ decade $(9.67 \%, 12$ cases $)$ and least was in $1^{\text {st }}$ decade $(3.22 \%, 4$ cases $)$ (Table 1$)$.

Table-1: Age distribution of spindle cell tumors

\begin{tabular}{|c|c|c|}
\hline Age (Years) & Number of Cases & Percentage (\%) \\
\hline $0-10$ & 4 & 3.22 \\
\hline $11-20$ & 14 & 11.29 \\
\hline $21-30$ & 30 & 24.19 \\
\hline $31-40$ & 22 & 17.74 \\
\hline $41-50$ & 23 & 18.54 \\
\hline $51-60$ & 12 & 9.67 \\
\hline$>60$ & 19 & 15.32 \\
\hline Total & $\mathbf{1 2 4}$ & $\mathbf{1 0 0}$ \\
\hline
\end{tabular}

Lower extremities were the most common site for soft tissue spindle cell tumors $(41.9 \%, 52$ cases) followed by upper extremities (23.38\%, 29 cases), abdomen (12.90\%, 16 cases), back and chest (12.09\%, 15 cases), head and neck ( $7.25 \%, 9$ cases) and least were in multiple sites $(2.41 \%, 3$ cases $)$ [Figure 1 ].

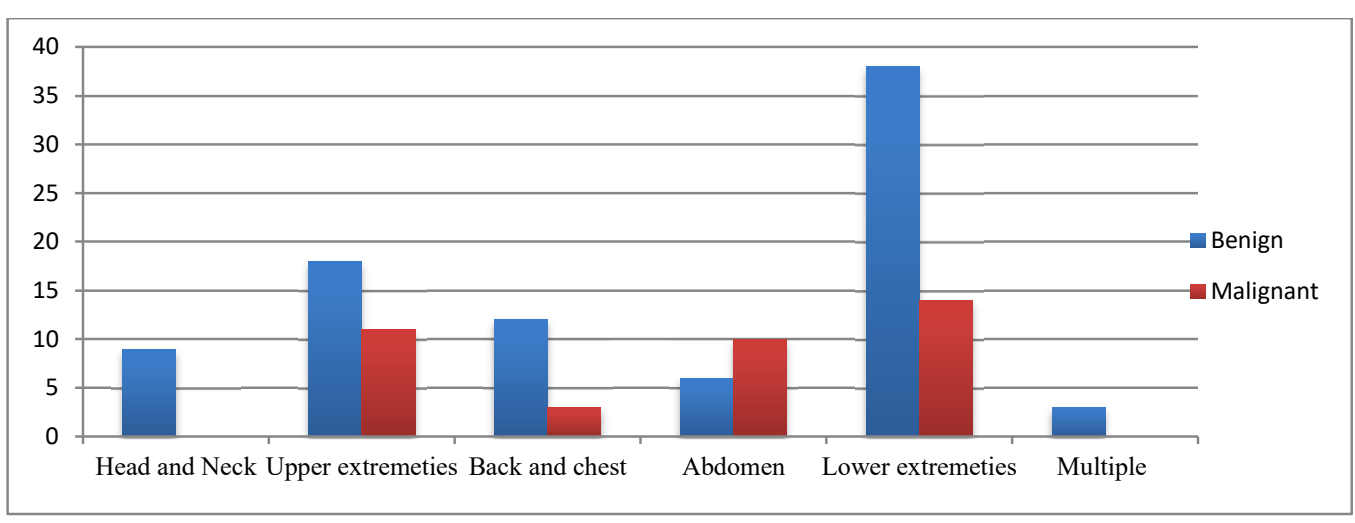

Figure-1: Bar graph showing site wise distribution of benign and malignant spindle cell tumors.

Cytological and histopathological correlation was available in 36 benign tumors and 16 malignant tumors. Among benign tumors, 94.44\% (34 cases) showed positive correlation, 5.56\% (2 cases) showed negative correlation. Whereas among malignant tumors, $93.75 \%$ (15 cases) showed positive correlation and 6.25\% ( 1 case) showed negative correlation between cytologic and histopathologic diagnosis [Table 2 and 3].

Table-2: Cytology-histopathology correlation of benign spindle cell tumors. 


\begin{tabular}{|c|c|c|c|c|}
\hline Cytologic diagnosis & No. & Follow up & Histo diagnosis & $\begin{array}{c}\text { Positive } \\
\text { correlation }\end{array}$ \\
\hline Schwannoma & 22 & 9 & 8 Schwannoma, 1 MPNST & $88.88 \%(8)$ \\
\hline Neurofibroma & 20 & 11 & $\begin{array}{c}9 \text { Neurofibroma, } 1 \\
\text { Neurilemmoma, } 1 \text { MPNST }\end{array}$ & $90.90 \%(10)$ \\
\hline $\begin{array}{l}\text { Inflammatory myofibroblastic } \\
\text { tumor }\end{array}$ & 2 & 0 & & \\
\hline Fibrous hamartoma of infancy & 1 & 0 & & \\
\hline Desmoid tumor & 8 & 4 & 4 Desmoid tumor & $100 \%(4)$ \\
\hline Fibromatosis & 3 & 1 & 1 Fibromatosis & $100 \%(1)$ \\
\hline Solitary fibrous tumor & 1 & 0 & & \\
\hline $\begin{array}{l}\text { Benign spindle cell tumor } \\
\text { (uncatergorised) }\end{array}$ & 29 & 11 & $\begin{array}{c}3 \text { Neurofibroma, } 2 \text { Desmoid } \\
\text { tumor, } 2 \text { BFH, } 1 \\
\text { Neurilemmoma, } 1 \text { Nodular } \\
\text { fasciitis, } 1 \text { Lieyomyoma, } 1 \\
\text { Superficial fibromyxoid tumor }\end{array}$ & $100 \%(11)$ \\
\hline Total & 86 & 36 & & $94.44 \%(34)$ \\
\hline
\end{tabular}

Table-3: Cytology-histopathology correlation of malignant spindle cell tumors

\begin{tabular}{|c|c|c|c|c|}
\hline Cytologic diagnosis & No. & Follow up & Histo diagnosis & Correlation \\
\hline Synovial srcoma & 5 & 2 & 2 Synovial sarcoma & $100 \%(2)$ \\
\hline DFSP & 3 & 2 & 2 DFSP & $100 \%(2)$ \\
\hline Fibrosarcoma & 4 & 2 & 2 Fibrosarcoma & $100 \%(2)$ \\
\hline MPNST & 6 & 3 & 3 MPNST & $100 \%(3)$ \\
\hline Sarcoma & 2 & 1 & 1 Leiyomyosarcoma & $100 \%(1)$ \\
\hline $\begin{array}{l}\text { Malignant spindle cell tumor } \\
\text { (uncategorized) }\end{array}$ & 18 & 6 & $\begin{array}{c}2 \text { MPNST } \\
1 \text { Synovial sarcoma } \\
1 \text { GIST } \\
1 \text { Malignant epithelioid } \\
\text { hemangioendothelioma } \\
1 \text { Pleomorphic lipoma }\end{array}$ & $83.33 \%(5)$ \\
\hline Total & 38 & 16 & & $93.75 \%(15)$ \\
\hline
\end{tabular}

There were 2 false negative cases which were cytologically diagnosed as Schwannoma and Neurofibroma because of the presence of wavy spindle cells and blood but both cases were diagnosed as malignant peripheral nerve sheath tumor on histopathology. There was 1 false positive case cytologically diagnosed as malignant spindle cell tumor but histopathologically diagnosed as Pleomorphic lipoma [Table 4].

Table-4: Statistical analysis.

\begin{tabular}{|c|c|c|c|}
\hline \multirow[t]{2}{*}{ Cytologic Diagnosis } & \multicolumn{2}{|c|}{ Histopathologic diagnosis } & \multirow[t]{2}{*}{ Total } \\
\hline & Benign & Malignant & \\
\hline Benign & 34 True Negative & 2 False Negative & 36 \\
\hline Malignant & 1 False Positive & 15 True Positive & 16 \\
\hline Total & 35 & 17 & 52 \\
\hline
\end{tabular}


Original Research Article

\section{Discussion}

The application of FNAC has led to the reasonably accurate diagnoses of various types of soft tissue tumors. Complex heterogeneity is a challenging factor in the diagnosis of soft tissue spindle cell tumors.

Present study was conducted on 124 patients who presented with soft tissue mass. Of these 86 cases $(69.35 \%)$ were cytologicaly diagnosed as benign spindle cell tumors and 38 cases (30.64\%) as malignant spindle cell tumors.

Results were comparable with the reports of other authors. Beg $\mathrm{S}$ et al reported 34 (24 benign and 10 malignant) cases as spindle cell tumors on cytology. On histopathology, there were 43 (32 benign and 11 malignant) cases [3]. Soni PB et al found $62.5 \%$ (45/72) cases of benign, $37.5 \%(27 / 72)$ cases of malignant spindle cell tumors on cytology [4]. Dey et al reported $67.34 \%$ cases (33/49) as benign and $32.65 \%$ cases (16/49) as malignant tumors [5].

Majority of soft tissue spindle cell tumors in the present study were between 21-30 years followed by 41-50 years. This was comparable to study done by Beg $\mathrm{S}$ et al in which majority of cases were between 21-30 years while Soni PB et al and Vijayabharati et al found that the most common age group for these tumors was between 21-30 years $[3,4,6]$.

We reported maximum number of spindle cell tumors in lower extremities 52 cases (41.9\%) followed by upper extremeties 29 cases $(23.38 \%)$ and abdomen 16 cases (12.9\%). Other authors like Dey et al, Vijayabharathi et al and Rekhi et al also found lower extremities as the most common site for spindle cell tumors $[5,6,7]$. Soni $\mathrm{PB}$ et al found upper extremeties as most common site whereas Beg et al found head and neck as most common site $[3,4]$.

In the present study, Schwannoma was the most common benign spindle cell tumor, Synovial sarcoma was the most common malignant tumor. Vijayabharathi et al. also reported the most common benign tumor as Schwannoma, Fibrosarcoma as most common malignant tumor [6]. Soni PB et al. reported neurofibroma as most common benign spindle cell tumor, MPNST as most common malignant tumor [4].

The criteria for malignancy as described by Kilpatrik SE et al [8] was that an aspirate is designated as a sarcoma when the smear shows moderate to high cellularity, hyperchromatic nuclei in almost all the sampled cells and ill-defined edges of the neoplastic fragments. Costa $\mathrm{MJ}$ et al [9] stated that in any aspirate from a spindle cell lesion, the main criteria to be assessed are cellularity, nuclear pleomorphism, mitosis and necrosis. Above criterias were considered in this study and majority of malignant spindle cell tumors diagnosed cytologically were uncategorized followed by 6 cases each of synovial sarcoma, MPNST and 4 cases of fibrosarcoma. In the present study, there was 1 false positive case and 2 false negative cases on FNAC giving sensitivity of $88.23 \%$, specificity of $97.14 \%$.

Exact subtyping of spindle cell tumors was a limiting factor in present study as well as other studies. A study on 70 spindle cell tumors by Vijayabharathi et al. revealed a $4 \%$ false positive rate [6].

Study by Beg S et al yielded 1 false positive and 1 false negative case. The change in cytological diagnosis on biopsy included 1 case of malignant fibrous histiocytoma (MFH) to benign fibrous histiocytoma (BFH). One case diagnosed as benign spindle cell tumor turned out to be synovial sarcoma thus giving $98 \%$ sensitivity and $96.7 \%$ specificity [3]. Soni PB et al, achieved $70 \%$ sensitivity and $100 \%$ specificity while dealing with these lesions [4].

Dey et al found 2 false positive cases, one case each of fibromatosis and schwannoma were reported as sarcoma. 3 False-negative cases were fibrosarcoma (1), malignant nerve sheath tumour (2) and haemangi-opericytoma (1) [5].

This was in contrast to the study by Rekhi et al. Who identified low false positivity with a sensitivity of $100 \%$ and specificity of $87 \%$ [7], Whereas Wakely et al noticed 1 false negative case out of 72 cases [10].

\section{Conclusion}

The sensitivity, specificity and diagnostic accuracy of fine needle aspiration cytology in distinguishing benign from malignant soft tissue spindle cell tumors was good and at par with other similar studies. Thus, we conclude that FNAC has a definite role in forming the initial diagnosis of soft tissue spindle cell tumors.

\section{What this study adds to existing knowledge?}

This study revealed that FNAC has a definite role in forming the initial diagnosis of soft tissue spindle cell tumors, while histopathology with the aid of ancillary techniques provides the final diagnosis leading to effective management. 


\section{Author's contribution}

Dr. Dhanya K.: Diagnosis collection of data and editing.

Dr. Sateesh Chavan S: Contributed in manuscript writing, editing and final review.

Findings: Nil; Conflict of Interest: None initiated Permission from IRB: Yes

\section{References}

1. Weiss SW, Goldblum JR. General Considerations. Chapter-1 In: Enzinger and Weiss's Soft Tissue Tumors. $4^{\text {th }}$ Edition, St. Louis: Mosby. 2001:1-19.

2.Rosenberg AE. Bones, Joints and Soft Tissue Tumors. Chapter-26 In: Robbins and Cotran Pathologic Basis of Disease by Kumar, Abbas and Fausto, $7^{\text {th }}$ Edition, Saunders: Elsevier, 2004;1273-1324

3.Beg S, Vasenwala SM, Haider N, Ahmad SS, Maheshwari V, Khan M. A comparison of cytological and histopathological findings and role of immunostains in the diagnosis of soft tissue tumors. J Cytol. 2012; 29 (2): 125-130. doi: 10.4103/0970-9371.97154.

4. Soni PB, Verma AK, Chandoke RK, Nigam JS. A prospective study of soft tissue tumors histocytopathology correlation. Pathol Res Int. 2014;2014: 678628. doi: 10. 1155/2014/ 678628. Epub 2014 Apr28.

5. Dey P, Mallik MK, Gupta SK, Vasishta RK. Role of fine needle aspiration cytology in the diagnosis of soft
Original Research Article

tissue tumours and tumour-like lesions. Cytopathol. 2004;15(1):32-37.doi:10.1046/j.0956-5507.2003. 00102.x

6. Loya AC, Prayaga AK, Arora A, Sundaram C, Rao IS, Uppin SG, et al. Lymph node metastasis of soft tissue tumors: a cytomorphologic study.Acta Cytol. 2007; 51(2): 153-160. doi: 10.1159/000325708

7. Rekhi B, Gorad BD, Kakade AC, Chinoy R. Scope of FNAC in the diagnosis of soft tissue tumors--a study from a tertiary cancer referral center in India. Cyto J. 2007;4:20. doi:10.1186/1742-6413-4-20

8. Kilpatrick SE, Cappellari JO, Bos GD, Gold SH, Ward WG. Is fine-needle aspiration biopsy a practical alternative to open biopsy for the primary diagnosis of sarcoma? Experience with 140 patients. Am J Clin Pathol. 2001;115(1):59-68. doi:10.1309/ YN14-K8U45FLJ-DGJE

9. Costa MJ, Campman SC, Davis RL, Howell LP. Fineneedle aspiration cytology of sarcoma: retros-pective review of diagnostic utility and specificity. DiagnCytopathol. 1996;15(1):23-32.doi:10.1002/(SICI) 1097-0339(199607)15:1<23::AID-DC6>3.0.CO; 2-R.

10. Wakely PE Jr, Kneisl JS. Soft tissue aspiration cytopathology. Cancer. 2000;90(5):292-298. doi: https: //doi.org/10.1002/1097-0142(20001025)90:5<292::

AID-CNCR5 $>3.0 . \mathrm{CO} ; 2-8$

\section{How to cite this article?}

Dhanya K, Sateesh Chavan S. A study on cytology of soft tissue spindle cell tumors with histopathological correlation wherever possible. Trop J Path Micro 2019;5(9):703-707.doi:10.17511/jopm.2019.i09.14. 